\title{
The Byzantian Hesychasm vs the Western Humanism (St. Nicholas Cabasilas on the True Dignity of the Human Person)
}

\author{
Shilov E* \\ Russian Orthodox University, Russia
}

*Corresponding author: Evgeny Shilov, Russian Orthodox University, 125183, Moscow, proezd Cherepanovykh, 72-40, Russia, Tel: +79162375058; Email: evgeny_shilov@mail.ru

\section{Research Article}

Volume 3 Issue 4

Received Date: October 27, 2020

Published Date: November 25, 2020

DOI: $10.23880 /$ phij-16000159

\section{Abstract}

Saint Nicholas Cabasilas (or Khamaet) is one of the major representatives of the Byzantian tradition of Hesychasm. In his works ("On the Life in Christ", "Commentary on the Divine Liturgy" and Homilies on the feasts of The Mother of God) he latently polemicizes with the Humanism (both Byzantian, and Western, Latin). And the main question, which the author never puts directly but which can be read between the lines, is the question of man: what is the real destination of the person, what is the purport of his life.

Keyword: Humanism; Philanthropy; Good of Man; God

Abbreviations: LCh: Nicholas Cabasilas. The Seven Words "On the Life in Christ"; CDL: Nicholas Cabasilas "Commentary on the Divine Liturgy"; Hom. Nat. MG: Nicholas Cabasilas "Homiliy on the Nativity of the Mother of God"; Hom. Ann. MG: Nicholas Cabasilas "Homiliy on the Annunciation of the Mother of God"; Hom. Dorm. MG: Nicholas Cabasilas "Homiliy on the Dormition of the Mother of God".

Saint Nicholas Cabasilas (or Khamaet) is one of the major representatives of the Byzantian tradition of Hesychasm. The secretary of emperor John VI Kantakouzenos, diplomat and ambassador, a close friend of Byzantian humanist Demetrios Kydones, a representative of the lay tradition of Hesychasm, all these are only a few characteristics of a many-sided person of the Greek theologian. In spite of the fact that his theological heritage is rather small, he is considered to be one of the best Church writers of the Medieval epoch.

The best known and popular work of St. Nicholas is The

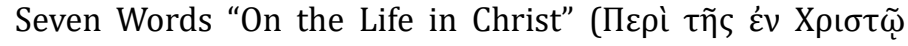
$\zeta \omega \tilde{\eta} \varsigma)$. In these Words the author writes that already in this earthly, created and corruptible world a Christian should start the life which will reach its full perfection only after death. This life is in the unity with Christ, which St. Nicholas calls a "marriage" of God with his creation, a "mixture" of the creation with its Creator. And this life is fulfilled in the Church through the sacraments (Baptism, Chrismation and the Eucharist).

He touches the same theme in his other - also wellknown work - "Commentary on the Divine Liturgy" where again he speaks on the Divine life which will be even more perfect in the world to come ( $\left.\varepsilon^{\prime} \sigma \chi \alpha \tau o v\right)$, nevertheless, it is the living experience in the present. Moreover, according to St. Nicholas, the communion with God in Christ through the Holy Spirit is the unique true purport of human life.

In this here that the Greek theologian latently polemicizes with the Humanism (both Byzantian, and Western, Latin). And the main question, which the author never puts directly but which can be read between the lines, is the question of man: what is the real destination of the person, what is the purport of his life, and, at last, the question which Immanuel Kant will express subsequently. "Was ist der Mensch?". On this the ways of the Eastern Hesychasm and the Western Humanism differ considerably. 


\section{Philosophy International Journal}

The aim of this talk is to characterize the doctrine of St. Nicholas Cabasilas on the true dignity of man, as it can be read in his works, and also to correlate his ideas with the ones of the Early Humanism. As this paper shows, it is possible to assume, that St. Nicholas latently polemicizes with the representatives of the Renaissance thought that is especially seen from his Homilies on the feasts of The Mother of God.

\section{The Human Person as a Co-Worker of God and the Tool of Philanthropy of God (Righteousness and Sanctity Before Christ)}

An Old Testament man before Christ's coming, is, according to St. Nicholas, "the old man". This person received "a seed of evil" from his ancestors at his birth, and he had no possibility of being cleansed from filthiness, from "the original sin". Moreover, this sinful illness more and more advances in mankind, alienating the person from God (LCh.2).

In the sixth Word of his work "On the life in Christ" St. Nicholas writes, that God has created the person as a certain final limit: his body was free from decay and his will was free from sin. The whole world was ready for man, and he came to the earth after all as "a criterion of everything". Man was entirely turned to the God - his nature, his will and his thoughts, and God was for him "a shelter of human desires", "a pleasure of his thoughts" and man initially wished to love nothing, but God and to think about God alone. It would have been, according to the author, "a failure to fulfill his duty and evasion from the beginning enclosed in his soul".

In the Homilies on the feasts of The Mother of God St. Nicholas Cabasilas writes a lot about the place of man in the Divine plan. It was important to him to show the role of the Virgin Mary not only in our salvation, but also as the summit which the man is capable to reach.

The sanctity of the Old Testament is imperfect sanctity, which is expecting its completion, even we can say "upset" as St. Nicholas writes: "before the coming of the Lord man could not rejoice, because the pleasure was brought to us by Christ alone" (CDL. 19). And consequently all life of mankind before Christ, all the achievements of mankind are merely "a certain forestalling and preparation for the solemn truth" (LCh. 4), because "personally and by our own means we could not show the truth" (Ibid.).

But the man wasn't left to his own resources. The God had enclosed in His creation "force against all sins" (Hom. Nat. MG V), but despite it, St. Nicholas writes, "nobody put it into action and nobody lived a life pure from faults, but the illness started from the first man, went to everybody and captured everybody, so, as it seemed, we had evil in our own nature" (Ibid.).

According to the Saint, sinfulness has been poured worldwide. "The flooding of rage got the heaven shut, and hell opened, and people involved in a war with God, and expelled the Good from the earth, and put in His place the Evil one" (Hom. Ann. MG. III).

St. Nicholas calls righteous men of the Old Testament "tools of God's philanthropy", "co-workers of God" (Hom. Nat. MG. II). But this righteousness is merely a shade of the future light, because in spite of the fact that many people in the Old Testament were called "saints", this term can be applied to them only "figuratively" (Hom. Dorm. MG. VIII). These righteous people were only the prototypes of true sanctity, which presented itself in the Incarnation of the Savior from the Most Holy Mother of God.

The Blessed Virgin Mary as a Fruit of the Righteousness of the Old Testament, As "The First Person" and As "The Proper End" of Every Creature

As St. Nicholas writes, "nobody was saint before the Blessed (Virgin Mary) came, but She as the first and the only one giving up sins completely, was a saint and the holy of holies" (Hom. Dorm. MG. VIII).

The figure of the Mother of God gets an important place in the theology of St. Nicholas Cabasilas. He devotes three Homilies to Her: on the Nativity of the Virgin Mary, on the Annunciation and on the Dormition of the Mother of God. She, in his opinion, was that unique person waited by the mankind from the moment of Fall. "She is alone of all people, - St. Nicholas writes, - who lived from the beginning of the world till now, opposed to every evil and She has returned to God her pure beauty, which She received from Him / ... / She put every sin to flight" (Hom. Nat. MG. VI). She "delivered God to people, destroyed the enmity between them, opened a way for prayers to Heaven, abolished partition wall of divisions" (Ibid. IV).

Thereby, the Mother of God showed the man as he had been initially created. Therefore, as St. Nicholas writes, "thanks to Her alone it was truly possible for the creature to learn his Creator. But before it neither law, nor prophets, nor the Creator's art shown in visible things, nor the heavens preaching the glory of its Creator (cf. Ps. 18,1), nor angelic cares and concerns, nor any other existing thing was strong enough to show divine goodness and wisdom. After all only man, bearing an image of God, if he is what he originally is, free from all faults, he can show God Himself" (Ibid. VI). 


\section{Philosophy International Journal}

The Virgin Mary was the "expectation of the earth" (Hom. Dorm. MG. III). She was the first to show the true sanctity. She was the first and the only one to "show the man" (Hom. Nat. MG. XVI) and therefore She became "the most comfortable of co-workers" of the Creator (Ibid. XVII), the only one, who was capable to apprehend and show God in Herself. As St. Nicholas writes: "So, the Most Immaculate (Virgin Mary) did not create man, but found the fallen one; did not give us the nature, but kept it; did not create, but promoted his recreation, became an assistant to the Founder and a coworker of the Artist. She has given to [man] what he had been before. God added what he had not been. But He would not have added the second if had not found the first" (Ibid.).

Since then the way of sanctity, the way of deification was open to man, because the Mother of God "became the sacred beginning and guide on the road to God" (Hom. Dorm. MG. VIII).

\section{The Uniqueness of Consideration of the Doctrine on the Virgin Mary Not from the Christological Point of View, but from the Anthropological One, The Latent Polemics with the Western Humanism}

We see here the unique characteristic of the theology of St. Nicholas Cabasilas. If the Fathers of Church before him while talking on the doctrine on the Virgin Mary underlined its Christological aspect (the Virgin Mary as Өвото́коৎ, the Mother of God), St. Cabasilas pays particular attention to its anthropological aspect, considering the Virgin as the summit of the mankind ("an proper crown" of all creatures), as summit which the person is capable to reach in his earthly life, as an image of a true sanctity.

It is possible to assume, that this aspect has been allocated by the Saint not casually. Nicholas Cabasilas knew the Latin tradition of theology (in many respects thanks to his friend Demetrios Kydones) ${ }^{1}$ and with immerging Humanism in the West (as well as in Byzantium). The main point of disagreements between Christian and humanistic systems is one of role of the man in the world. Humanists proclaim an autonomy of human mind, its independence from God. For humanism God is impenetrable and inaccessible Essence. Cabasilas, in his turn, tries to show what the true dignity of man is and what his true renaissance is. And for the sake of it he appeals to the personality of the Most Holy Mother of God. Man is not autonomic, and theonomic, he is connected with

1 Congourdeau, Marie-Hélène. 'Nicolas Kabasilas et la théologie latine' in: Antonio Rigo, Pavel Ermilov (eds.). Byzantine Theologians. The Systematization of Their Own Doctrine and Their Perception of Foreign Doctrines (Roma,

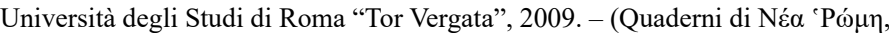
3)). 169-179.
God and all his being is turned to Him. And consequently the main moment of human history - the Incarnation of the Son of God - was, according to him, not only the work of triune God, but also the one of the will and faith of the Virgin Mary. This conjunction of two wills resolved the tragedy of human freedom.

\section{Self-sufficiency and Autonomy of Man in Humanism and «A Life in Christ» in Hesychasm}

One of the major problems of Christian theology is the problem of the position of man in the world and of human nature. Man is not simply a biological species, not a mere link in a food chain, but a visible image of invisible God. The person is correlated with God, and only such a correlation justifies and explains human existence. The encounter and the union of man with God, as well as the taste of uncreated divine energies is also a "justification" of $\operatorname{man}^{2}$. He is seeking God in order to return to the lost Paradise. From this point of view, the deification, the connection between the created (material and spiritual space) and the un-created (triune God) is an ultimate goal of all our undertakings and the beginning of man's returning to the primeval state of integrity and beatitude.

Man for St. Nicholas Cabasilas is the summit of creation, the purpose of creation. The deification through God's divine grace is an accomplishment of the union between God and man, which is understood by the Saint as the union between man and the divine nature of Christ. Therefore he defines man not psychologically, but Christologically. Man grows through his cooperation with Christ, through his imitating Christ, through participating in Church sacraments. This cooperation between man and his Creator ("synergy") is "life in Christ".

In the Orthodox doctrine of St. Nicholas Cabasilas and the one of humanists it is possible to single out four basic differences in the view of the place of man in this world and man's dignity. They are the following:

1) The relations with God (autonomy in Humanism vs "life in Christ" of Cabasilas).

2) The mode of life (aspiration to glorify in Humanism vs asceticism of Hesychasm).

3) The ultimate goal of man (happiness in Humanism vs the deification in Cabasilas).

4) The ideal of man (homo universalis et intellectualis of Humanism vs the figure of the Virgin Mary in the doctrine of Cabasilas).

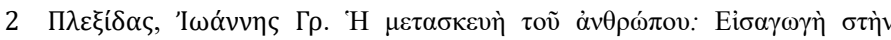

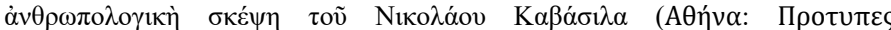

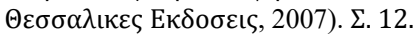




\section{Philosophy International Journal}

Let's look at each point more closely.

\section{A) The Relation with God}

If we speak about early Humanism of times of Nicholas Cabasilas, there is no doubt, that it was not atheistic Humanism. But at the same time, it also was not truly Christian. Humanists criticized Christianity and tried to work out a replacement to it. The Byzantine and Western humanists constantly attacked Christian beliefs, but on the other hand it was in religion that they found a basis for individual and social moral. Religion could not be abolished, it had to be "renewed", altered for a new image of man. Here humanists reasoned in a spirit of Voltaire, that "if God doesn't exist, He should be invented".

If in the Middle Ages the culture was theocentric, in the Renaissance drew God out the bounds of its ideology. The transcendental God ceased to be considered for humanists the main problem, because He was transcendental. In the new humanistic world-view the man took the place of God. Man became "the criterion of the world" (Leonardo da Vinci), "the divine person"3.

For St. Nicholas Cabasilas, man who departed from God is self-centered. This self-sufficiency of man put him out of relations with his Creator. Man translated a natural dialogue into a monologue and suffered the paradox of irrational loneliness, because he considered himself, without God, capable to achieve his purpose. The man withdrawn into himself, became blind and not capable to communion with $\mathrm{God}^{4}$. It leads to the death of his soul, and man completely tore himself from the channels of fellowship with God. True human life is "a life in Christ" and is carried out in the Church through co-working, through the "synergy" between man and God.

\section{B) The Mode of Life}

Early Humanists are characterized by the concern for literary glory, ambitions, love for their works, the idea of immortality, achieved by literary glory. For example, Theodore Metochites, Nikephoros Choumnos, Nicephorus Gregoras, Thomas Magister (Theodulos Monachos) and others in their letters and treatises often demonstrated a burning desire to write such a composition which would immortalize them forever ${ }^{5}$. We see the same ambition of laurels and glory in Dante Alighieri and Petrarch. In last canticle of his "Divine Comedy", Dante addresses Apollo with the request to grant him force for his inspiration, necessary for a poetic description of the

3 Khlodovskij R. I. Franchesko Petrarka: Poeziya gumanizma. - Moscow: Izdatelstvo "Nauka", 1974.

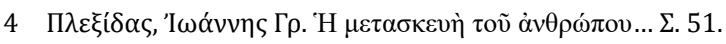

5 Medvedev I. P. Vizantijskij gumanizm XIV-XV vv. - SPb.: Izdatelstvo "Aletejya", 1997. P. 32-33.
Paradise and he expresses confidence, that his work will receive due compensation. Petrarch who is under a debt of gratitude to Dante, also expresses "non Christian vanity". Glory for him is beyond virtue, as it is seen in his well-known speech on the Capitol in April 1341. Man should not wait for favors from God and immortality in the future life, but to labor on his immortality here and now, in order to live for his descendants in his works forever - such is the motto of early Humanism.

St. Nicholas Cabasilas, being the spokesman for the traditions of Hesychasm, takes the opposite point of view. In fact, the man should try to earn immortality and eternal life here and now, he writes about it quite often. But this immortality is earned not by glory of this world, on the contrary, through the removal from this world for the sake of true life with God. Cabasilas even opposes people searching for earthly glories. In the second word of his "On a life in Christ" he writes: "For there can be nothing more corrupted than a comedian and none loves wisdom more than a martyr". Only the man, who loves Christ above all, and who is capable of defying all the good of this world for God's sake, - only he is worthy to be called a true disciple of Christ. Otherwise man becomes like Judas Iscariot, who "exchanged God and Savior for a small silver" (LCh. 7), and all these is because the man forgot about God and ceased to love Him. Not surprisingly St. Nicholas pays a lot of attention to the theme of martyrdom for Christ, because true love of God does not allow man to become attached to earth and to be afraid of death.

\section{C) The Ultimate Goal of Man}

For humanists man himself, humanity and happiness were the purpose of human life. This happiness can be achieved in this world if man develops creative principles put in him by the nature. The ultimate goal was seldom discussed by early humanists. Basically, humanists touched upon particular problems, not reflecting on the final aim of life.

For St. Nicholas Cabasilas the ultimate goal of man is deification, the real unity of man and God which starts already in this life - through the Sacraments of the Church. This deification, the sanctity is "the greatest of all God's gifts" (CDL. 49), it is "a fruit of all blessings which the Lord bestowed to the mankind" (Ibid). The father writes: "For this purpose there is Paradise, for this purpose there are the prophets, for this purpose God took the flesh and for this purpose there is the divine doctrine, and deeds, and sufferings, and death (of Christ), - for people to move from earth to Heaven and to become the heirs of the Heavenly Kingdom" (Ibid).

In the Homilies on the feasts of The Mother of God St. Nicholas also raise a question on the purpose of human life. And he answers, that God created man beyond all the creations "to love solely God, to live in conformity with 
reason, to rule over passions and not to fall into any sin" (Hom. Nat. MG. V).

\section{D) The Ideal of Man}

Humanism offered a new concept of man. It is the ideal of a citizen (homo civilis) who is urged to play an active role in the life of the state, the intellectual enlightened and educated (homo eruditus, homo universalis). Humanism is inseparable from culture as a whole and from the scientific progress. Man is in this world and should live in this world. For humanists man is first of all the creator (the author). This is a creature who is developing the world, improving, decorating and regulating it. Giannozzo Manetti in his treatise "On the Dignity of Man" ("De dignitate et excellentia hominis") even names man as "a well-wishing assistant to God", because, while accepted the imperfect and unfinished world from God, man brings it to perfection by his labors and inventions. The Lord is the Creator, and man is a creator too, because he makes everything better, than it was primarily, he improves what God only planned, he invents what it was not invented primarily ${ }^{7}$.

Petrarch (Francesco Petrarca) speculates, that exclusively man should be the object of philosophy, and solely experience, first of all an internal experience of man, that is self-knowledge and self-discovery should be its method. "Being mortal, I only tend to mortal" - such is the motto of Petrarch.

Byzantian humanists of the XIV century considered man from the same horizontal perspective. For example, Gemistus Pletho writes, that man is not only "a sack of flesh"

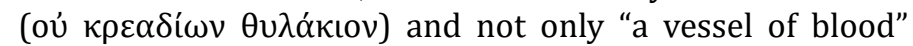

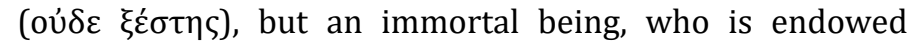
with reason. According to Pletho, man is "an intermediate border" ( $\mu \varepsilon \theta$ Ө́pıov) and a "clamp" ( $\sigma u ́ v \delta \varepsilon \sigma \mu o \varsigma)$, "a clamp of the world" (an equivalent to Latin copula mundi). But as man is bipolar, dual, made of two natures - of divine and animal beginnings, - he is always inwardly un-integral, fragmented and disunited. And this duality in man is deeply rooted and

6 Manetti, Dzhannoczczo. O dostoinstve i prevoshodstve cheloveka. - Moscow: Politicheskaya enciklopediya, 2014. P. 72.

7 Revyakina NV. 'Chelovek $i$ mir v traktate Dzhannoczczo Manetti' in: Manetti, Dzhannoczczo. O dostoinstve i prevoshodstve cheloveka. - Moscow: Politicheskaya enciklopediya, 2014. P. 17.

ineradicable. Out of here comes pessimism which penetrates the compositions of both Byzantine, and Italian humanists.

\begin{abstract}
For St. Nicholas Cabasilas the ideal of man, as it has already been told above, is the Virgin Mary, who showed to the mankind such sanctity to which each Christian should aspire. The Most Holy Mother of God reached the peak of sanctity (Hom. Ann. MG. III). She "is incomparably more glorious than Heavenly minds" (CDL. 49) and that is only thanks to Her that the Lord descended to the earth for the sake of our salvation. And if for the early Humanism the ultimate goal, anyhow, remains vague and not clear, for Christians it is salvation and deification, and an example how to achieve it is set before our eyes - that is of the Holy Mother of God.
\end{abstract}

\section{References}

1. Congourdeau MH (2009) 'Nicolas Kabasilas et la théologie latine'. In: Antonio R, Pavel E (Eds.), Byzantine Theologians. The Systematization of Their Own Doctrine and Their Perception of Foreign Doctrines (Roma, Università degli Studi di Roma “Tor Vergata”, pp: 169179.

2. Khlodovskij RI (1974) Franchesko Petrarka: Poeziya gumanizma. - Moscow: Izdatelstvo "Nauka”.

3. Manetti D (2014) O dostoinstve i prevoshodstve cheloveka. - Moscow: Politicheskaya enciklopediya

4. Medvedev IP (1997) Vizantijskij gumanizm XIV-XV vv. SPb.: Izdatelstvo "Aletejya".

5. Nikolaj Kavasila (2007) Hristos. Cerkov. Bogorodicza. Moscow: Izdatelstvo hrama sv. mcz. Tatiany.

6. Revyakina NV (2014) 'Chelovek i mir v traktate Dzhannoczczo Manetti' in: Manetti, Dzhannoczczo. O dostoinstve i prevoshodstve cheloveka. - Moscow: Politicheskaya enciklopediya, pp: 3-23.

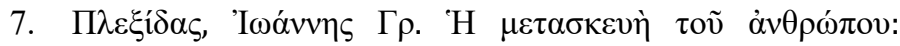

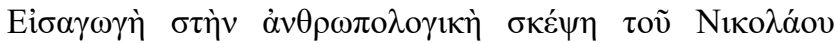

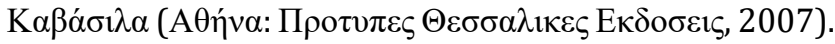

